\title{
RITUAL CÍVICO E POLÍTICA NA REAÇÃO MONÁRQUICA: RIO DE JANEIRO E SALVADOR, 1837-41 ${ }^{1}$
}

Hendrik Kraay ${ }^{2 ; 3}$

\section{Resumo}

Este artigo analisa as dimensões políticas dos esforços para promover o ritual cívico monárquico da parte dos governos da época do Regresso de 1837 até a coroação do imperador d. Pedro II em julho de 1841. Tendo em foco as cidades do Rio de Janeiro e Salvador, argumenta que essas comemorações devem ser compreendidas como uma continuação da política partidária que profundamente moldou os festejos e a cobertura jornalística dos mesmos.

\section{Palavras-chave}

Coroação - Regresso - festas cívicas - d. Pedro II - política partidária.

\section{CIVIC AND POLITICAL RITUAL IN THE MONARCHIC REACTION: RIO DE JANEIRO AND SALVADOR, 1837-41}

\section{Abstract}

This article examines the political dimensions of the Regresso era governments' investment in monarchical civic ritual from 1837 to the coronation of emperor d. Pedro II in July 1841. Focusing on the cities of Rio de Janeiro and Salvador, it argues that these celebrations should be understood as an extension of partisan politics, which profoundly shaped the celebrations and the newspaper coverage of them.

\section{Keywords}

Coronation - Regresso - civic rituals - d. Pedro II - partisan politics.

\footnotetext{
${ }^{1}$ Apresentei parcialmente o argumento deste artigo em KRAAY, Hendrik. Days of national festivity in Rio de Janeiro, Brazil, 18231889. Stanford: Stanford University Press, 2013. cap. 3. Revisão do português de Isabel Fandino e de Pedro Falk. A pesquisa contou com financiamento do Social Sciences and Humanities Research Council (Canadá) e da Coordenação de Aperfeiçoamento do Pessoal Superior (Brasil).

As seguintes abreviaturas são usadas nas notas: AGCRJ (Arquivo Geral da Cidade do Rio de Janeiro), AIHGB (Arquivo do Instituto Histórico e Geográfico Brasileiro), AN/SPE (Arquivo Nacional, Seção do Poder Executivo), APEBa/SACP (Arquivo Público do Estado da Bahia, Seção de Arquivo Colonial e Provincial), BN/SI (Biblioteca Nacional, Seção de Iconografia), CM (Correio Mercantil, Salvador), JC (Jornal do Commercio), NARS (National Archives and Records Service), PRO/FO (Public Record Office, Foreign Office), Rio (Cidade do Rio de Janeiro). A não ser que seja indicado, os periódicos citados foram publicados no Rio.

${ }^{2}$ Universidade de Calgary. Calgary - Alberta - Canadá.

${ }^{3}$ Hendrik Kraay é professor de História na Universidade de Calgary, Alberta, Canadá. Doutorou-se pela Universidade de Texas em 1995. É autor de Política racial, Estado e forças armadas na época da Independência: Bahia, 1790-1850. São Paulo: Hucitec, 2011, além de muitos artigos publicados em periódicos. Seu livro Bahia’s independence: popular politics and patriotic festival in Salvador, Brazil, 1824-1900, está no prelo pela McGill-Queen’s University Press. E-mail: kraay@ucalgary.ca.
} 
O dia do décimo segundo aniversário de d. Pedro II amanheceu chuvoso, o que muito decepcionou o almirante britânico Graham Eden Hamond. Do convés do seu navio, ancorado no porto do Rio de Janeiro, Hamond percebeu que "foram tomadas várias providências para fazer este dia o mais alegre possível"4. Na véspera do dia 2 de dezembro de 1837, a câmara municipal tinha convidado os moradores das ruas Direita e de São Pedro a iluminarem as fachadas das suas casas e ornarem "com cortinas, as frentes e janelas" para saudar o monarca que faria a sua tradicional entrada desde o palácio de São Cristóvão até o centro da cidade. O fiscal da freguesia de Santana lembrou aos moradores que tivessem "as testadas de suas casas perfeitamente limpas" e alcatifadas "com odoríferas folhagens". Tanto o Jornal do Commercio como o almirante mencionaram "os riquíssimos coches que acab[ar]am de chegar da Inglaterra" e que seriam usados pela primeira vez; o almirante ouviu dizer que as viaturas e seus arreios custaram 15.000 libras esterlinas ${ }^{6}$.

A chuva deu uma trégua e a procissão imperial saiu de São Cristóvão às $15 \mathrm{~h} 45 \mathrm{~m}$. No Rocio da Cidade Nova (atual praça 11), o jovem monarca foi recebido por "vivas aclamações do imenso concurso que ansioso o esperava". No começo da rua de São Pedro, quatro crianças fantasiadas de anjos "lançaram flores sobre os coches imperiais, e dez meninos vestidos de branco com fitas verdes deram a liberdade a pombos que eles seguravam entre os braços". "Lindíssimas damas e cavalheiros se apinhavam nas janelas para saudarem a passagem" do imperador ${ }^{7}$. O largo do Paço (atual praça 15) estava lotado quando o imperador chegou - Hamond nunca tinha visto tanta gente na praça e havia mais concorrência ao te-déum e ao cortejo no paço da cidade do que nos últimos anos 8 . A Guarda Nacional fez suas continências ao imperador e às princesas, suas irmãs, e os guardas deram os vivas de costume. À noite houve um espetáculo de gala no teatro de São Pedro, onde uma nova peça alegórica, o Prólogo dramático, de Manoel de Araújo Porto Alegre, foi representada ${ }^{9}$. Embora não fossem registrados pelos jornais da Corte, durante o cortejo, dois ministros e muitos outros oficiais e funcionários públicos beijaram a mão do jovem imperador, restabelecendo efetivamente o tradicional beija-mão que havia sido abandonado em 1831 depois da abdicação de d. Pedro I. No dia anterior, o novo regente, Pedro de Araújo Lima (o futuro marquês de Olinda), havia dado o tom ao beijar a mão do imperador numa festa religiosa ${ }^{10}$.

O Sete de Abril, sob orientação de Bernardo Pereira de Vasconcelos, ministro da Justiça e dos Negócios do Império no novo ministério (gabinete de 19 de setembro de 1837, o do Regresso), explicou que o entusiasmo manifestado no dia demonstrava que "a atual administração em muito concorre para desassombrar os espíritos timoratos". O Parlamentar, periódico ligado aos ex-ministros Francisco Gê Acaiaba de Montezuma e Antônio Paulino Limpo de Abreu, no entanto, esperava o dia 2 de dezembro de 1843 para que o novo monarca assegurasse que "a constituição triunfe sempre", crítica pouco velada ao ministério ${ }^{11}$. N'O Cronista, o jornalista defensor do Regresso, Justiniano José da Rocha, julgou que, à medida que o Brasil se aproximava da maioridade de d. Pedro II, o futuro "ia perdendo de sua incerteza" ${ }^{\prime 2}$. De fato, ainda havia muitas incertezas, principalmente as revoltas que sacudiam três províncias. Os rebeldes do Rio Grande do Sul e do Pará se sublevaram há mais de dois anos e, há menos de um mês, a rebelião baiana (posteriormente conhecida como a Sabinada) havia declarado a Bahia "inteira e perfeitamente desligada" do Brasil, enquanto durasse a minoridade do imperador ${ }^{13}$.

${ }^{4}$ HAMOND, Graham Eden. Os diários do almirante (...), 1825-1834/38. Tradução de Paulo F. Geyer. Rio: Editora J. B., 1984. p. 176. ${ }_{5}^{5}$ Editais, 28 e 29/11/1837, JC, 30 de novembro de 1837.

${ }^{6} J C, 1$ de dezembro de 1837; HAMOND, Graham Eden. Os diários... Op. Cit., p. 176.

${ }^{7}$ SILVA, Pereira da. O Dia Dous de Dezembro. JC, 4 de dezembro de 1837, JC, 5 de dezembro de 1837.

${ }^{8}$ HAMOND, Graham Eden. Os diários... Op. Cit., p. 176. Outros diplomatas estrangeiros concordaram com essa avaliação: BARMAN, Roderick J. Citizen emperor: Pedro II and the making of Brazil, 1825-1891. Stanford: Stanford University Press, 1988. p. 64.

9 SILVA, Pereira da. O Dia Dous de Dezembro. JC. Op. Cit. Sobre essa peça, ver KRAAY, Hendrik. Days of national festivity in Rio de Janeiro, Brazil, 1823-1889. Stanford: Stanford University Press, 2013. p. 233-234.

${ }^{10}$ A data do gesto de Araújo Lima é de um periódico de 1860 que identificou o dia como o vigésimo terceiro aniversário da restauração do costume. Primeiro de dezembro e a beija-mão. O Regenerador, 1 de dezembro de 1860 . Ver também BARMAN, Roderick J. Citizen emperor ... Op. Cit., p. 64.

11 Anniversario de S. M. o Imperador. O Sete d'A bril, 6 de dezembro de 1837; Dous de Dezembro. O Parlamentar, 2 de dezembro de 1837.

12 O Chronista, 2 de dezembro de 1837.

${ }^{13}$ Sobre a Sabinada ver KRAAY, Hendrik. “Tão assustadora quanto inesperada”: a Sabinada baiana, 1837-1838. In: DANTAS, Mônica Duarte (org.). Revoltas, motins, revoluções: Homens livres pobres e libertos no Brasil do século XIX. São Paulo: Editora Alameda, 2011. p. 263-294; SOUZA, Paulo Cesar. A Sabinada: A revolta separatista da Bahia (1837). São Paulo: Brasiliense, 1987. 
$\mathrm{Na}$ Bahia, tanto os rebeldes - liberais exaltados e militares insatisfeitos - como os legalistas se esforçaram para festejar o aniversário do monarca. Os sabinos pediram desculpas pela falta de pompa, pois muitos dos seus novos soldados ainda não tinham fardas. Entretanto, o Novo Diário da Bahia descreveu uma respeitável comemoração ao "Glorioso Aniversário do natalício do Senhor D. Pedro II". Houve salvas de artilharia de madrugada, ao meio dia e ao anoitecer, bem como o tradicional cortejo à imperial efígie, iluminação dos edifícios públicos à noite e o enterro solene de um soldado morto nos combates. Segundo Paulo Cesar Souza, os canhões dos navios da Marinha imperial também salvaram, dando um tom surreal ao ritual. Essas comemorações concorrentes demonstram o poder simbólico do monarca para ambos os lados ${ }^{14}$. Essa lealdade ao imperador convenceu um empregado do arsenal da Marinha de que nada havia mudado desde a eclosão do movimento em 7 de novembro. Visto que ainda "tremulava a mesma bandeira e (...) se davam vivas à sua majestade o Senhor D. Pedro II", julgou conveniente voltar ao serviço, decisão que o levou ao tribunal depois da derrota dos rebeldes ${ }^{15}$. Decretos posteriores da Sabinada indicaram uma rejeição mais firme à monarquia: em janeiro foi ordenado que fossem apagadas as inscrições da pirâmide erguida em 1815 para comemorar a chegada de d. João VI e a abertura dos portos, pois não convinha celebrar "um déspota sanhudo e ingrato [que] veio infeccionar[-nos] com o bafo pestífero da corte portuguesa" ${ }^{\text {" }}$.

Face às revoltas nas províncias e inseguro quanto à sua posição na capital, o Ministério dos Capazes (como também era conhecido o gabinete de 19 de setembro) tentou se fortalecer através do ritual cívico. Além de investir na pompa e no fausto das comemorações do aniversário do monarca, o gabinete recorreu aos jornais para divulgar sua interpretação da festa cívica, como se fazia desde o surgimento da imprensa no Brasil. Porém, não se podia impedir a publicação de notas destoantes da sua linha política. Ainda em fevereiro de 1838, o Jornal do Commercio publicava atos oficiais do governo da Sabinada e O Parlamentar continuaria a culpar o gabinete pela eclosão do movimento baiano até a véspera da tomada de Salvador (ocorrida em 15 de março e conhecida na Corte em $1^{\circ}$ de abril $)^{17}$. Os relatos sobre as festas cívicas publicadas nos jornais eram textos políticos, através dos quais os detentores do poder procuravam legitimar-se ao associarem-se aos símbolos poderosos da monarquia (bem como a Constituição e a Independência comemoradas nos outros principais dias de festejo nacional, 25 de março e 7 de setembro). As fortes clivagens partidárias se manifestavam na cobertura jornalística das festas cívicas. Como observou Justiniano em 1841, "no grau de irritação a que chegaram os partidos em nossa pátria, é absolutamente impossível que um festejo nacional reúna o zelo de todos os cidadãos" ${ }^{18}$. O governo - é bom lembrar que houve importantes mudanças ministeriais em 1837, 1839, 1840 e 1841 - sempre se apresentava como o verdadeiro defensor da monarquia e das instituições imperiais. Os que estavam fora do poder não rejeitavam esses símbolos poderosos; pelo contrário, lamentavam sua incapacidade de aproveitá-los e conspiravam para retomálos. Conforme a observação de Justiniano, a oposição sempre procurava desqualificar as festas cívicas do governo. Assim, o ritual não era um campo autônomo, divorciado da política convencional; era mais um campo no qual os brasileiros travavam suas lutas políticas.

A partir de uma leitura dos jornais da época, este artigo analisa as dimensões político-partidárias da comemoração do aniversário de d. Pedro II de 1837 a 1840, bem como os festejos da sua coroação no Rio de Janeiro e em Salvador, as duas maiores cidades do Império. A coroação, realizada em 18 de julho de 1841 na Corte e festejada na capital baiana em 7 de setembro do mesmo ano, foi a maior festa cívica até então organizada pelo Império. Tanto essa quanto a comemoração do dia 2 de dezembro eram festas oficiais, organizadas pelo governo. Através delas, o governo imperial (e o governo provincial na Bahia) procurava legitimar-se perante a população e difundir a imagem de um império ordeiro, civilizado e estável, unido em torno do seu maior símbolo. Todavia, uma leitura cuidadosa dos periódicos da época revela intensas lutas políticas mal disfarçadas pela retórica oficial, além de indícios de releituras populares do ritual oficial.

\footnotetext{
${ }^{14}$ Ordem do Dia 683, 30/11/1837. JC, 14 de dezembro de 1837; Novo Diario da Bahia (Salvador), 6 de dezembro de 1837; SOUZA, Paulo Cesar. A Sabinada... Op. Cit., p. 72-73, 158-191.

${ }^{15}$ Interrogatório de Luiz Ferreira Braga, Salvador, 20 de agosto de 1838. Processo crime contra os empregados da Marinha, fol. 164r, Apeba/SACP, m. 2835

${ }^{16}$ Decreto, 27/01/1838. JC, 15 de fevereiro de 1838.

17 A Revolução da Bahia. O Parlamentar, 31 de março de 1838.

18 Os festejos da coroação. O Brasil, 13 de julho de 1841.
} 
Muito foi escrito sobre os rituais das coroações, gerando uma farta documentação. Não pretendo analisar a coroação de d. Pedro II como "um grande ato de comunhão nacional" como fizeram Edward Shils e Michael Young no seu famoso artigo sobre a coroação de Elisabete II em 1952 ${ }^{19}$. A visão durkheimiana deles - e de muitos outros estudiosos do ritual medieval - já foi bastante criticada ${ }^{20}$. Clifford Geertz chama atenção à importância do ritual político que serve como manifestação simbólica do poder, mas na sua análise do estado-teatro balinês, na qual "o poder servia à pompa e não a pompa ao poder", não há espaço para política ${ }^{21}$. O antropólogo David Kertzer sustenta que é através da ambiguidade de seus significados que o ritual "produz laços de solidariedade sem exigir uniformidade de crenças" ${ }^{\prime 2}$. Essa abordagem - que destaca a polissemia dos rituais - nos ajuda a compreender o ritual ć́vico durante esses anos, quando diversos grupos lutavam pelo controle desse poderoso símbolo brasileiro. Afinal de contas, tanto os partidários do Regresso como a oposição se diziam verdadeiros defensores da monarquia.

\section{A construção da monarquia através do ritual cívico}

As festas monárquicas, cada vez mais pomposas, apenas parcialmente escondiam a intensa política partidária desses anos finais da Regência. Não cabe nesse artigo uma análise pormenorizada das questões políticas em jogo nos últimos anos da Regência, que giravam principalmente em torno da centralização do poder através da interpretação do Ato Adicional, a criação do novo aparato policial e do tráfico de escravos, cuja defesa era uma bandeira dos saquaremas. Os saquaremas, uma aliança de ex-moderados e ex-caramurus, com fortes raízes na classe de senhores de engenho do Rio de Janeiro e do Norte, ligados aos comerciantes e aos burocratas da Corte, dominaram o Partido da Ordem (o núcleo do futuro Partido Conservador). Este formou o ministério do Regresso (o gabinete de 19 de setembro de 1837). Além de reforçar o Estado através de ajustes às reformas liberais, os saquaremas procuravam fortalecê-lo simbolicamente através da divulgação do simbolismo monárquico ${ }^{23}$. Para os regressistas, as reformas liberais haviam, desde o final da década de 1820, abalado a ordem no Brasil e era preciso restaurá-la através do fortalecimento das instituições tradicionais como a monarquia.

Apesar do enfraquecimento do ministério do Regresso (que caiu em abril de 1839), emergia certo consenso em torno das suas principais políticas. A morosidade das operações militares contra os rebeldes do Norte e do Sul e a percepção de que a ordem social ruía contribuíram fortemente para esse consenso. A precoce maturidade do jovem imperador sugeria que ele já tinha condições de assumir as rédeas do poder, o que asseguraria o princípio da ordem no país. À medida que a centralização e a prematura maioridade ganhavam apoio, acirravam-se as lutas pelo poder. A maioridade proclamada em 23 de julho de 1840 foi um golpe parlamentar - ou mesmo uma "revolução" como a qualificou o ministro dos Estados Unidos - através da qual uma aliança heterogênea de oposicionistas (o cerne do futuro Partido Liberal) destituiu o regente e o ministério identificado com os princípios do Regresso. Eles defendiam a manutenção das instituições existentes, de feição liberal-moderada, como a autonomia provincial, a predominância do Poder Legislativo sobre o Executivo e a continuação das restrições ao Poder Moderador impostas em 1831. Para manter sua posição, precisavam controlar a monarquia. Convenceram o jovem a logo assumir o poder e não em data futura (talvez no seu décimo quinto aniversário como planejava o gabinete). Líderes do Regresso, inclusive Vasconcelos, se opuseram à proclamação imediata da maioridade ${ }^{24}$.

\footnotetext{
19 SHILS, Edward; YOUNG, Michael. The meaning of the coronation. Sociological Review, vol. 1, n. 2, p. 80, dezembro de 1953.

${ }^{20}$ BIRNBAUM, N. Monarchists and sociologists: a reply to professor Shils and Mr. Young. Sociological Review, vol. 3, n. 1, p. 5-24, julho de 1955; BUC, Phillippe. The dangers of ritual: between early medieval texts and social scientific theory. Princeton: Princeton University Press, 2001.

21 GEERTZ, Clifford. Negara: The theater state in nineteenth century Bali. Princeton: Princeton University Press, 1980. p. 13.

22 KERTZER, David I. Ritual, politics, and power. New Haven: Yale University Press, 1988. p. 67

${ }^{23}$ Sobre o Regresso ver BARMAN, Roderick J. Brazil: the forging of a nation, 1798-1852. Stanford: Stanford University Press, 1988. p. 189-205; NEEDELL, Jeffrey D. The Party of Order: the conservatives, the state, and slavery in the Brazilian monarchy, $1831-1871$. Stanford: Stanford University Press, 2006. p. 73-80; BASILE, Marcello. O laboratório da nação: A era regencial (1831-1840). In: GRINBERG, Keila; SALLES, Ricardo (org.). O Brasil imperial. Rio de Janeiro: Civilização Brasileira, 2009. vol. 2: 1831-1870, p. 90-94; PARRON, Tâmis. A politica da escravidão no Império do Brasil, 1826-1865. Rio de Janeiro: Civilização Brasileira, 2001. p. 121-191; CASTRO, Pedro Paulo. A “experiência republicana”, 1831-1840. In: HOLANDA, Sérgio Buarque de. História geral da civilização brasileira. São Paulo: Difusão Europeia do Livro, 1964. tomo 2, vol. 2: Dispersão e unidade, p. 53-60.

${ }^{24}$ Sobre a política da Maioridade, ver BARMAN, Roderick J. Brazil ... Op. Cit., p. 198-211; Idem. Citizen emperor ... Op. Cit., p. 68dossiê Regência e Imprensa
} 
No Rio de Janeiro, foi organizado às pressas um espetáculo de gala para a noite do dia 23; o poeta e jornalista Francisco de Paula Brito aconselhou o "Príncipe amado" a escolher um ministério de "Homens, que possam de Teu Régio Sólio / Sustentar o esplendor na Europa inteira / Homens que prezem mais que a própria vida / Sua honra, Senhor, e a Tua glória" ${ }^{25}$. A cidade foi iluminada durante algumas noites, enquanto "bandas de música percorriam as ruas da cidade, acompanhadas do povo, dando numerosos e repetidos vivas à Maioridade”. A maioria dessas manifestações era pacífica, mas a casa de Vasconcelos foi apedrejada e Mary Hunter (esposa do ministro norte-americano) assustou-se com uma "procissão turbulenta que ia ao palácio levando archotes e soltando foguetes"26.

A notícia da maioridade chegou à Bahia na primeira semana de agosto; o presidente Tomás Xavier Garcia de Almeida logo pediu demissão, mas ficou com a administração da província até a chegada do seu sucessor. O Correio Mercantil publicou longos relatos do que havia ocorrido na capital e, no dia 9, o governo provincial festejou a nova ordem com todos os elementos de uma festa cívica ${ }^{27}$. No teatro de São João, Francisco Muniz Barreto (poeta há muito tempo ligado aos exaltados) recitou um novo hino: "Salve, de Pedro Segundo / Salutar Maioridade! / Salve almejado Tesouro / De paz e felicidade! / Parabéns, Pátria ditosa! / Respira, exulta, ó Bahia! / Nossos destinos mudaram: / Completou-se a monarquia / Patriótica Assembleia / Para salvar a Nação / Antecipou de Pedro / Suspirada Aclamação ${ }^{28}$. Os festejos continuaram até o final do mês, quando foi realizado um baile que reuniu a elite da cidade ${ }^{29}$. Pouco depois chegou à Bahia a notícia da anistia de 22 de agosto que pôs fim à repressão dos aderentes à Sabinada.

O ministério indicado por d. Pedro II em 24 de julho estava longe do ideal dos servidores desinteressados recomendado ao monarca por Paula Brito. O jovem imperador premiou os líderes da campanha em prol da maioridade. O "Ministério dos Três Antônios" (Antônio Carlos Ribeiro de Andrada Machado e Silva, Antônio Paulino Limpo de Abreu e Antônio Francisco de Paula e Holanda Cavalcanti de Albuquerque) era heterogêneo, unido principalmente por sua oposição ao projeto regressista. Daí decorria sua defesa das reformas liberais dos primeiros anos da Regência. O ministério presidiu as notórias "eleições do cacete" no final do ano nas quais conseguiu eleger uma maioria na Câmara dos Deputados prevista para se reunir em 1842, mas esse gabinete caiu em março de $1841^{30}$.

Não obstante a feição política do golpe da Maioridade, a decisão de confiar o governo ao jovem monarca decorria logicamente do destaque dado à monarquia desde o começo do Regresso. Já em 1838, o ministro dos Estados Unidos, William Hunter, percebeu "um sistema de rodear [o imperador] com pompa e esplendor", o que ele julgou "talvez útil"31. Nesse ano, foram construídos diversos monumentos efêmeros na capital para as festas do aniversário do imperador. Entre esses, destacava-se o "magnífico arco" na rua Direita, ornado de "várias legendas em obséquio ao imperador e ao seu dia natalício, bem como os nomes das dezoito províncias". Depois do espetáculo de gala, o imperador e as princesas fizeram um "passeio verdadeiramente triunfal" pelas ruas da cidade para conhecer os outros monumentos ${ }^{32}$.

73; NEEDELL, Jeffrey D. Op. Cit., p. 80-95; BASILE, Marcello. Op. Cit., p. 94-97; CASTRO, Pedro Paulo. Op. Cit., p. 61-66. Sobre a formação de D. Pedro II ver BARMAN, Roderick J. Citizen emperor... Op. Cit., p. 39-41, 51-52, 55-56. Para avaliação da maioridade como uma revolução ver William Hunter para o secretário do Estado. Rio, 31 de julho de 1840, NARS, M-121, rolo 14.

25 Canto ao Dia 23 de Julho de 1840. A Mulher de Simplicio ou A Fluminense Exaltada, 1 de dezembro de 1840.

${ }^{26}$ JC, 25-26 de julho de 1840; HUNTER, Mary Robinson. A diplomat's lady in Brazil: selections from the diary of Mary Robinson Hunter, 1834-1848. Organização de Evelyn M. Cherpak. Newport: Newport Historical Society, 2001. p. 173.

$27 \mathrm{CM}, 6,7$ e 8 de agosto de 1840 .

${ }^{28}$ Hymno composto pelo Sr. F. Moniz Barreto, e cantado no theatro publico desta cidade, na noite de 9 do corrente. CM, 12 de agosto de 1840.

29 BERTRAND, Arthur. Lettres sur l’expédition de Saint-Hélène en 1840. Paris: Paulin, 1841. p. 45.

${ }^{30}$ Para essa qualificação do gabinete de 24 de julho, ver BARMAN, Roderick J. Brazil ... Op. Cit., p. 209-211; NEEDELL, Jeffrey D. Party... Op. Cit., p. 95-101.

${ }^{31}$ Hunter para o secretário do Estado, Rio, 22 de dezembro de 1838. NARS, M-121, rolo 13. Ver também BASILE, Marcello. Op. Cit.,p. 95.

32 O Dia 2 de Dezembro. O Despertador, 3 de dezembro de 1838; Festejos do dia 2 de dezembro. JC, 4 de dezembro de 1838. Os festejos desse ano foram muito bem documentados por visitantes norte-americanos: JENKINS, John S. United States exploring expeditions (...). Auburn: James M. Alden, 1850. p. 42-43; WILKES, Charles. Narrative of the United States exploring expedition during the years 1838, 1839, 1840, 1841, 1842. Nova ed. Nova York: George P. Putnam, 1851. vol. 1, p. 49; REYNOLDS, William. Voyage to the Southern Ocean. Organização de CLEAVER, Anne Hoffman; STANN, E. Jeffrey. Annapolis: Naval Institute Press, 1988. p. 34-36; COGGESHALL, George. Thirty-six voyages to various parts of the world, made between the years 1799 and $1841.3^{\text {a }}$ ed. Nova York: Published by and for the Author, 1858. p. 548-550. 
Ano após ano, observadores brasileiros e estrangeiros insistiam que as festas do dia 2 de dezembro haviam excedido as festas do ano anterior ${ }^{33}$. Em 1839, havia mais monumentos; no ano seguinte, as festas duraram três noites. No seu diário, d. Pedro II registrou que gostou do arco levantado pelos eleitores da freguesia de Engenho Velho e que não apreciou a "iluminação adjunta" que para "nada prestava". Essa representava o jovem imperador e suas irmãs "sobre um rochedo" e seus pais "por entre as nuvens abençoando-os com os braços estendidos à maneira de quatro paus e muito mal pintados". $\mathrm{Na}$ maioria desses monumentos havia música, "uma coisa principal", e imagens do imperador em contextos alegóricos, com versos para explicar o seu sentido. Num arco, o estudioso monarca reconheceu "latim (...) bem feito, um hexâmetro e um pentâmetro" ${ }^{34}$. Medíocres em sua maioria, esses versos, todavia, apresentavam mensagens claras. O arco de 1839, na esquina da rua de São Pedro com a rua de São Domingos, tinha uma imagem da "Concórdia e a Paz acariciando o Gênio do Brasil". Os versos explicavam que o monarca, apoiado pelas duas, daria ao país: "Santas leis, e valor, patriotismo / As artes e o comércio afortunando / As letras e as ciências em porfia. / Tu és nossa esperança, e nosso anelo / Amparo nosso, do Brasil amparo / Nosso brasão, dever, glória e desvelo". Infelizmente, a descrição dessa alegoria publicada n'O Despertador não indica como o gênio do Brasil foi retratado pelo artista ${ }^{35}$.

O surto de entusiasmo pela monarquia parece não ter impressionado o jovem imperador. Em dezembro de 1840, escreveu duas vezes no seu diário sobre a interminável "maçada" das suas obrigações $^{36}$. A opinião particular do homenageado não afetou as comemorações e poucos criticavam abertamente os espetáculos. O consenso em torno da monarquia era forte demais na Corte e Barman comenta a "euforia geral" que rodeava a monarquia ${ }^{37}$. Todavia, certo "Antiquário" observou em 1838 que nunca havia sido o costume festejar os aniversários dos monarcas com iluminações; essa honra era reservada aos nascimentos dos príncipes, mas a "súcia regressista" a havia estendido ao aniversário do imperador: "Estes hipócritas não querem só o regresso, querem o que escapou ainda aos mais servis, e baixos sevandijas dos tempos de El-Rei seu senhor!" ${ }^{88}$ Com a restauração do beija-mão e o destaque dado ao ritual monárquico, parecia que o Brasil estava voltando ao passado colonial. Mas, vale a pena repetir, os rituais e os símbolos desse passado estavam nas mãos de determinados grupos políticos. Justiniano lembrou depois que os arcos de 2 de dezembro de 1840 eram obra dos Andradistas (graças ao seu apoio à Maioridade, tanto Antônio Carlos como seu irmão, Martim Francisco Ribeiro de Andrade, serviam no ministério) ${ }^{39}$. Todos valorizavam suas próprias manifestações de apoio à monarquia e desqualificavam as dos seus rivais.

$\mathrm{Na}$ Bahia, nos festejos do dia 2 de dezembro, destacava-se a repressão à Sabinada ${ }^{40}$. Em $1838 \mathrm{e}$ 1839, o Correio Mercantil publicou relatos pormenorizados dos festejos na Corte para chamar atenção à lealdade baiana ao Império ${ }^{41}$. O presidente Tomás Xavier Garcia de Almeida, homem forte da repressão, relatou que o dia 2 de dezembro de 1838 havia sido comemorado "com a maior pompa, e entusiasmo imaginável", avaliação que o Correio Mercantil secundou ${ }^{42}$. O viajante norte-americano, Daniel Kidder, assistiu aos festejos de 1839 e os julgou uma manifestação de "fidelidade ao trono".

\footnotetext{
${ }_{33}$ Para 1838 ver HUNTER, Mary Robinson. A diplomat's...Op. Cit., p. 117; O Dia 2 de Dezembro. O Sete d'Abril, 5 e dezembro de 1838. Para 1839 ver João Loureiro para Manuel José Maria da Costa e Sá, Rio, 29 de novembro de 1838, Revista do Instituto Histórico e Geográfico Brasileiro, vol. 76, n. 2, p. 444-445, 1914; Anniversario natalicio de S. M. O Senhor D. Pedro II”.JC, 01 de dezembro de 1839; Festejos ao Dia 2 de Dezembro. JC, 4 de dezembro de 1839; Os Festejos do Dia Dous de Dezembro. O Despertador, 4 de dezembro de 1839; BARMAN, Roderick J. Citizen emperor... Op. Cit., p. 69 (citando a avaliação de um diplomata francês). Para 1840, ver HUNTER, Mary Robinson. A diplomat's...Op. Cit., p. 184; 2 de Dezembro. O Despertador, 3 de dezembro de 1840.

34 PEDRO II. Diários. Petrópolis: Museu Imperial, [1999], 3 de dezembro de 1840. [CD-ROM]

35 Os festejos do dia Dous de Dezembro. O Despertador, 4 de dezembro de 1839.

${ }^{36}$ PEDRO II, Diários ... Op. Cit., 2 e 4 de dezembro de 1840. Para os relatos da imprensa ver Os Festejos do Dia 2 de Dezembro. JC, 2-3 de dezembro de 1840; Os Festejos do Dia 2 de Dezembro. A Regeneração, 4 de dezembro de 1840.

37 BARMAN, Roderick J. Citizen emperor... Op. Cit., p. 74.

38 Correspondência ao redator. O Filho do Sete d'Abril, 4 de dezembro de 1838.

39 Os festejos da coroação. O Brasil, 13 de julho de 1841.

${ }^{40}$ Sobre a política baiana depois da Sabinada ver ARAUJO, Dilton Oliveira. O tutu da Bahia: transição conservadora e formação da nação, 1838-1850. Salvador: EdUFBa, 2009.

41 CM, 3 de janeiro de 1839; 8 e 9 de janeiro de 1840.

${ }^{42}$ Tomás Xavier Garcia de Almeida para Manoel Antônio Galvão, Salvador, 10 de dezembro de 1838. AN/SPE, IJJ9, vol. 338, fol. 27r; CM, 4 de dezembro de 1838 .
} 
Houve iluminação da cidade durante três noites e os moradores enfeitaram as fachadas das suas casas. O viajante ouviu falar que, durante o te-déum, o pregador havia condenado o seu país como "herético e republicano". Dois mil e quinhentos guardas nacionais desfilaram nas ruas principais e no Passeio Público havia um "pavilhão em estilo de templo grego" para abrigar "um grande retrato de Sua Majestade"; depois do presidente tirar o véu, essa efígie imperial foi saudada por "ruidosas aclamações do povo". O obelisco desfigurado à ordem da Sabinada estava provisoriamente coberto por dísticos iluminados: "Pedro esse nome Augusto, / Simboliza união, integridade / Prosperidade e ordem / Paz, duração, grandeza e liberdade" ${ }^{43}$.

Uma comissão de doze negociantes organizou o festejo do Passeio, durante o qual foi distribuído um panfleto para explicitar o significado do ritual cívico. O "Hino, que devem entoar os amantes do Brasil" resumiu o argumento do panfleto: "Só PEDRO e a Carta / Com igualdade / A liberdade / Podem manter / (...) / Retalhando o grande Império / De pouco pode valer / Unidos tudo podemos / Integridade ou morrer". Qualquer tentativa de mudar a ordem política, como destacou o artigo principal, traria a "vingança celeste" e questionar a monarquia, como haviam feito os sabinos, seria uma afronta à "inocência, contra a Justiça Natural, contra a Paz Pública, contra as Leis, contra a Santidade dos Juramentos, e contra DEUS"44.

Apesar dessa impressionante demonstração de lealdade ao imperador, a Maioridade não foi aceita de bom grado pelo grupo dominante na Bahia, pois parecia reverter o quadro político em favor dos sabinos e seus simpatizantes na Corte. O Correio Mercantil, o único periódico baiano disponível para essa época, saudou a Maioridade, mas logo passou à oposição aberta ao novo gabinete e, portanto, silenciou-se diante da comemoração de 2 de dezembro de 1840, pois preferiu não comentar festejos que legitimavam os então detentores do poder ${ }^{45}$.

Da mesma forma, na Corte, os periódicos avaliavam os festejos do dia 2 de dezembro conforme suas orientações políticas. Desde 1831, a monarquia servia como instrumento da salvação do Brasil, argumentavam os periódicos regressistas; era o "símbolo em que personificar a ordem e a liberdade". Com certa frequência, seus redatores observavam que o jovem imperador descendia de reis ilustres, mas, nascido no Brasil, era um verdadeiro americano ${ }^{46}$. Os oposicionistas condenavam os abusos do ministério do Regresso e anelavam a maioridade do imperador, quando "nos ha[via] de tirar do inferno em que os devoristas nós têm posto" ${ }^{47}$. Em 1839, outro comentou que não se devia concentrar as festas cívicas no dia 2 de dezembro, pois 7 de setembro era tão importante quanto o aniversário do imperador: foi o "dia majestoso em que a nossa querida Pátria começou a figurar entre as nações", argumento que subordinava o imperador à pátria ou à nação ${ }^{48}$. Em 1840, A Regeneração procurou equivaler o "Quero já" do segundo imperador ao "Fico" do seu pai em 9 de janeiro de 1822, pois ambos os atos haviam salvo o país da anarquia que então o ameaçava. Apesar de insistir que o dia 2 de dezembro não era "dia de partidos", seus elogios à Maioridade denunciavam o apoio do periódico ao gabinete de 24 de julho ${ }^{49}$.

A poesia desses anos sempre saudava d. Pedro II como o instrumento da salvação do Brasil; recitados no palco antes dos espetáculos de gala no teatro, pintados nos arcos triunfais, publicados nos jornais, esses versos não deixavam dúvidas quanto à visão dominante do jovem imperador. Dois sonetos são mais que suficientes para não enfadar os leitores. No baile realizado no palácio do governo baiano em 3 de dezembro de 1839, Ladislau dos Santos Titara lembrou a história recente e ansiava um futuro melhor:

\footnotetext{
${ }^{43}$ KIDDER, Daniel P. Sketches of residence and travels in Brazil. Philadelphia: Sorin \& Ball, 1845. vol. 2, p. 60-61.

${ }^{44}$ SERVA, Manoel Antônio da Silva. O Dous de Dezembro de 1839 (...). Salvador: Typ. de Manoel Antônio da Silva Serva, 1839. p. 5 , $18,19,22-24,27$.

45 Bahia: Noticias diversas. CM, 4 de dezembro de 1840.

${ }^{46}$ Ver os editoriais: CM, 4 de dezembro de 1838; O Despertador, 1 de dezembro de 1838, 3 de dezembro de 1839; O Sete d’Abril, 2 de dezembro de 1838; JC, 3 de dezembro de 1838, 1 de dezembro de 1839; O Instincto, 3 de dezembro de 1839.

47 O Parlamentar, 5 de dezembro de 1838; O Filho do Sete d'Abril, 4 de dezembro de 1838.

48 O Dia 2 de Dezembro de 1839. A Liga Americana, 5 de dezembro de 1839.

$\underline{49}$ O Dia 2 de Dezembro e Ainda o Dia 2 de Dezembro. A Regeneração, 2 de dezembro de 1840.
} 
Por todo o Império, a um tempo, audaz se erguera

Ensanguentado o Monstro da Anarquia

Com ele assolações, Discórdia ímpia,

Mortes, horror, e infâmia atroz fervera

Fratricidas punhais, oh dor! Morrera

A mão vil da Ambição, da Tirania

E a vera Liberdade, a monarquia

Quase, entre abismos, quase se perdera

O Teu mágico Nome, ó Pedro Amigo

Então invocam leais brasilianos

Contra o comum verdugo, o atroz inimigo:

Surge a Paz, vence a Lei, baqueiam danos

És o Anjo da União, És o Pátrio Abrigo:

Quanto dure o Brasil, durem Teus Anos ${ }^{50}$.

No Rio de Janeiro, certo J. G. S. Louzada também saudou o imperador e esperava sua maioridade:

Eu te adoro, ó de Pedro sagro dia!

De dezembro o dois, ó dia desejado!

Aos teus inimigos, firme e ousado

Tu vences com indizível alegria.

Dos brasileiros corações, és dia

De esperança, de amor, dia sagrado

Com sincero prazer és celebrado

Com cânticos suaves de harmonia.

Recebe, pois, ó príncipe ditoso!

$\mathrm{O}$ tributo de um povo que festeja

Seu monarca inocente, generoso

O povo do Brasil, contente almeja

Que teu governo seja assaz honroso

A Jove rogo, responda que "assim seja" ${ }^{51}$.

Essas poesias, parte integral da retórica monárquica, que incluía os artigos de fundo dos jornais, a arquitetura efêmera e a própria prática do ritual cívico, revelam os temores e os anseios dos brasileiros que não imaginavam seu futuro político sem um papel central para o monarca. Leitores e ouvintes atentos, todavia, discerniam facilmente as simpatias políticas do poeta ou inferiam-nas do contexto em que apareciam os versos.

Essa comemoração do monarca e a luta política pelo controle desse símbolo também moldaram sua coroação. É importante reconhecer que o ritual cívico e os relatos sobre esse ritual faziam parte

${ }_{50}$ TITARA, Ladislau dos Santos. Soneto ao faustissimo anniversario natalício (...). In: Obras poeticas dedicadas á Ill. ${ }^{m a}$ Senhora D. Ignacia Maria de Carvalho Lima. Salvador: Typ. de G. J. Bizerra e Companhia, 1839. p. 183.

51 LOUZADA, J. G. S. Soneto. JC, 6 de dezembro de 1839. 
integral da política. Embora os membros da elite política brasileira compartilhassem interesses de classe, estavam fortemente divididos a nível político-partidário; não havia ritual cívico que reconciliasse as facções políticas rivais que lutavam pelo poder. Quando os preparativos para a coroação já estavam bem adiantados, em 23 de março de 1841, o gabinete que resultou da Maioridade caiu. O novo ministério, composto de homens estreitamente ligados ao Regresso, conseguiu uma maioria na câmara dos deputados para a aprovação das reformas que centralizariam o poder; também presidiu à coroação ${ }^{52}$.

\section{A coroação e a política, 1841}

A coroação de d. Pedro II, enfim realizada em 18 de julho de 1841, foi sem dúvida o maior ritual cívico do Império brasileiro. Pouco se tem escrito sobre essa cerimônia em comparação à literatura sobre a coroação de d. Pedro I intimamente ligada a criação do Império ${ }^{53}$. Lilia Moritz Schwarcz sustenta que a coroação foi um "ritual por parte das elites (...) um golpe das elites e para as elites", e acrescenta que a "riqueza do ritual e a força de sua divulgação levaram a uma explosão do imaginário popular" que incluía releituras importantes da monarquia ${ }^{54}$. Separar a coroação da política e da onda de rituais monárquicos dos quatro anos anteriores levou a exagerar o grau de consenso entre a elite e a constatar que é muito difícil comprovar que um surto de monarquismo popular resultou da coroação, embora haja alguns indícios instigantes. O que é claro, todavia, é que as autoridades se esforçaram para excluir as classes populares dos espaços centrais dos festejos ao tentarem organizar um ritual para a elite. Houve tentativas semelhantes na capital baiana, mas era mais difícil controlar o espaço urbano soteropolitano.

Logo depois da Maioridade, precisava-se marcar a data da coroação. D. Pedro II queria ser coroado no seu próximo aniversário, quando faria quinze anos, mas em agosto o gabinete o convenceu a adiála até o início de maio, quando começaria a sessão parlamentar ${ }^{55}$. Em março, falava-se em adiar a função até o dia 23 de maio ou mesmo até junho, pois os preparativos estavam atrasados. O ministro britânico, William Gore Ouseley, julgou que esses atrasos eram um meio através do qual o governo procurava controlar o parlamento ${ }^{56}$. Houve muita incerteza nos primeiros dias de maio até que o dia 18 de julho foi indicado, decisão que desagradou muitos que haviam chegado ao Rio de Janeiro para assistir à função e agora tinham que escolher entre permanecer na capital ou voltar para casa e repetir a viagem $^{57}$. Em junho, ainda se falava em adiamento até setembro ${ }^{58}$.

Não se sabe quanto custou a coroação e o governo não divulgou as contas. Ouseley estimou que foram gastos "alguns milhões de mil-réis". Muito mais tarde, um republicano calculou as despesas em quase 554 contos (553:912\$002), quatro vezes mais do que os 147 contos votados pelo Parlamento (ambas essas cifras eram bem menores do que foi estimado por Ouseley) ${ }^{59}$. A estrutura efêmera principal, a varanda ao lado oeste do largo do Paço, projetada por Porto Alegre (que recebeu o

\footnotetext{
52 Sobre as reformas do gabinete de 23 de março de 1841, ver BARMAN, Roderick J. Brazil... Op. Cit., p. 212-213.

${ }^{53}$ LOPEZ, Emilio Carlos Rodrigues. Festas públicas, memória e representação. São Paulo: Humanitas, 2004. p. 235-336; SOUZA, Iara Lis Franco Schiavinatto Carvalho. Pátria coroada: O Brasil como corpo político autônomo, 1780-1831. São Paulo: Editora Unesp, 1998. p. 256-281; RIBEIRO, Maria Eurydice de Barros. Os símbolos do poder: cerimônias e imagens do Estado monárquico no Brasil. Brasília: UnB, 1995. p. 71-78; OLIVEIRA, Eduardo Romero. O império da lei: ensaio sobre o cerimonial de sagração de d. Pedro I (1822). Tempo, vol. 13, n. 20, p. 133-159, 2009; SCHUBERT, Guilherme. A coroação de d. Pedro I. Rio de Janeiro: Arquivo Nacional, 1973; CARDOSO, Ângela Miranda. Ritual: princípio, meio e fim. Do sentido do estudo das cerimônias de entronização brasileiras. In: JANCSÓ, Istvan (org.). Brasil: formação do Estado e da nação. São Paulo: Hucitec; Ijuí: Unijuí, 2003. p. 549-602.

${ }^{54}$ SCHWARCZ, Lilia Moritz. As barbas do imperador: d. Pedro II, um monarca nos trópicos. 2a ed. São Paulo: Companhia das Letras, 1999. p. 83; Idem. O Império em procissão. Rio de Janeiro: Jorge Zahar, 2001. p. 20-21, 32-33. Para uma descrição do ritual que segue de perto a cobertura jornalística ver SANTOS, Francisco Marques dos. Dom Pedro II e a preparação da Maioridade. Estudos Brasileiros, vol. 3, n. 7, p. 40-140, julho a dezembro de 1941.

55 BARMAN, Roderick J. Citizen emperor ... Op. Cit., p. 78; Circular, 18/08/1840. CM, 1 de setembro de 1840.

${ }^{56}$ William Gore Ouseley para o visconde de Palmerston, Rio, 1 de março de 1841, PRO/FO 13, vol. 169, fols. 154r-155r. Ver também KIDDER, Daniel. Sketches of residence... Op. Cit., vol. 2, p. 371; Hunter para o secretário do Estado, Rio, 21 de abril de 1841. NARS, M-121, rolo 14.

${ }^{57}$ HUNTER, Mary Robinson. A diplomat's... Op. Cit., p. 195; O Adiamento da Sagração de S. M. o Imperador. O Despertador, 07 de maio de 1841.

${ }^{58}$ A Coroação. O Brasil, 12 de junho de 1841; Ouseley para Palmerston, Rio, 14 de junho de 1841 (reservado), PRO/FO 13, vol. 171, fol. 82 .

59 Ouseley para Palmerston, Rio, 07 de julho de 1841, PRO/FO 13, vol. 171, fol. 265r; BOTAFOGO, Antônio Joaquim de Sousa. O balanço da dynastia. Rio: Imprensa Nacional, 1890. p. 18-22.
} 
salário altíssimo de 250 mil-réis mensais para supervisionar a sua construção), custou pelo menos 61:276\$169. O tesoureiro da obra confessou durante a construção que não podia prever o preço final ${ }^{60}$. A câmara municipal nem tentou orçar as suas despesas e simplesmente solicitou autorização para gastar o que era preciso ${ }^{61}$. Os diplomatas norte-americanos e britânicos se preocupavam com as despesas que incorreriam e reclamaram da "extorsão" da parte dos lojistas, alfaiates e donos de coches de aluguel. Hunter e Ouseley invejavam seus colegas português e dinamarquês (bem como o núncio apostólico) que receberam subsídios especiais para se apresentarem de maneira conveniente; o norteamericano lamentou que teve que gastar mais de 600 dólares do seu próprio bolso ${ }^{62}$. Sem dúvida, muitos brasileiros tiveram que abrir mão de avultadas quantias para participar da cerimônia.

A fim de preparar o largo do Paço, o município despachou mais operários para a obra do aterro nas docas para aumentar a praça, já que se esperava que a mesma estivesse lotada durante a cerimônia ${ }^{63}$. Mais importante foi remover as classes populares, entre elas as quitandeiras que ocupavam a praça no lado do mar, como recomendou o fiscal da freguesia da Candelária. Logo gracejou um jornalista que era mais fácil "privar os rios o desaguarem no mar" do que impedir a infiltração de tal gente nas multidões dos festejos públicos ${ }^{64}$. A julgar por uma sátira posterior, a polícia também tentou afastar escravos: "Soube o chefe de Polícia / Tomar medida segura / Para que não transitasse / Entre o povo a escravatura. / E assim do Monarca em frente / De escravos a imensidade / O não guiou dando vivas / Pelas ruas da cidade" 65 .

Houve outras tentativas de assegurar um público seleto na festa e de atender às suas necessidades. Certo G. Neuville solicitou autorização para construir na praça uma arquibancada ao lado do mar para 1.200 espectadores. Pelo preço módico de $2 \$ 000$ por pessoa, as famílias gozariam de "um lugar mais decente" e estariam "isentos dos incômodos causados pela multidão". A Câmara negou esse pedido e, aos que queriam se distanciar da multidão, só restava a opção de reservar uma mesa na varanda do hotel do Império; segundo o jornalista satírico, era "para regalar os olhos", só para quem "não [se] importa[va] [em] assassinar a bolsa". Talvez por cobrar um preço exorbitante, o hotel ainda não tinha alugado todas as mesas no dia 14 de julho ${ }^{66}$.

Limpar e enfeitar a cidade eram outras preocupações das autoridades. Os arsenais forneceram bombas para molhar as ruas, a fim de que não ficassem "indecentemente cobert[as] de poeira, como tem acontecido mais de uma vez em dias de grande gala”. Os fiscais das freguesias receberam ordens para espalhar nas ruas por onde passaria o préstito folhas de mangueiras, que seriam fornecidas pelo Jardim Botânico; segundo Alexandre José de Mello Moraes Filho, muitos escravos foram empregados nessas tarefas ${ }^{67}$. Os donos das casas foram instados a caiar suas fachadas e a iluminar as janelas por nove noites, a partir do dia 16 de julho ${ }^{68}$. O chefe de polícia proibiu "aos particulares o soltar girândolas, ou outro qualquer fogo de artifício" durante a entrada, para não assustarem os cavalos ou ofenderem os dignitários ${ }^{69}$.

A Câmara municipal avaliou várias propostas para entretenimento público durante os festejos. O dono de um museu de história nacional queria construir um "lindo gabinete" no largo do Paço para mostrar suas coleções. Seria "científico, e próprio para divertir o público, e conforme pratica-se em semelhantes ocasiões nas cortes estrangeiras (...). O golpe de vista dos objetos raros e curiosos (...) fará um competente elogio a esse grande país rico de tantos produtos da natureza”. A Câmara

\footnotetext{
60 Ver as contas em AN/SPE, códice 569, fols. 143-158.

61 Documento sem título, 05 de fevereiro de 1841. AGCRJ, 6-2-25, fol. 41.

${ }^{62}$ HUNTER, Mary Robinson. A diplomat's... Op. Cit., p. 192; Hunter para secretário do Estado, Rio, 21 de abril de 1841. NARS, M-121, rolo 14; Ouseley para Palmerston, Rio, 1 de março de 1841. PRO/FO 13, vol. 169, fol. 153r-154r; Hunter para o secretário do Estado, Rio, 15 de setembro de 1841. NARS, M-121, rolo 14.

63 Documento sem título nem data. AGCRJ, 6-2-25, fol. 36.

${ }^{64}$ Fiscal, freguesia da Candelária, para Câmara, Rio, 1 de julho de 1841. AGCRJ, 41-3-22, fol. 6r; As testemunhas materiaes presenciadoras da coroação (comunicado). JC, 6 de maio de 1841.

65 Os Festejos da Coroação. A Mulher de Simplicio ou A Fluminense Exaltada, 28 de julho de 1841.

66 As testemunhas (...). JC, 6 de maio de 1841; Anúncios. O Despertador, 14 de julho de 1841.

${ }^{67}$ Correspondência. JC, 14 de julho de 1841; Documento sem título, 3 de julho de 1841. AGCRJ, 6-2-25, fol. 34; MELLO MORAES FILHO, Alexandre José de. História e costumes. Rio: B. L. Garnier, 1904. p. 106.

68 Edital, 19/05/1841. JC, 9 de julho de 1841; Declarações. O Despertador, 15 de julho de 1841; Editaes. JC, 15 de julho de 1841.

69 Edital. O Despertador, 13 de julho de 1841.
} 
aprovou a proposta, mas Porto Alegre julgou que não havia espaço disponível no largo e o museu foi deslocado para o Campo da Aclamação ${ }^{70}$. Não havia preocupações quanto à decência do museu, mas o homem que propôs erigir "uma barraca para jogos olímpicos e outros de várias qualidades na praça da Aclamação" foi advertido de que sua estrutura fosse "de prospecto elegante, iluminada" e construída no lugar indicado pelo fiscal ${ }^{71}$. Os irmãos Benard solicitaram licença para montar uma barraca para "jogos hidráulicos" tanto para as festas do Espírito Santo (em 30 de maio em 1841) como para a coroação; foi aprovada somente para a festa religiosa popular ${ }^{72}$.

Enquanto havia certo consenso em torno da necessidade de apresentar uma cidade respeitável, limpa e civilizada, outras questões eram mais difíceis. O Maiorista - cujo título anunciava sua filiação ao grupo que promovera a Maioridade - não cansava de criticar o ministério por avaliar tudo relacionado à coroação "na balança de suas mesquinhas paixões". Muitos indivíduos dignos não foram convidados. Quando José Clemente Pereira, o então ministro da Guerra, foi indicado para carregar a espada do Ipiranga no préstito do dia 18, o jornal condenou essa honra dada ao "chefe dos recolonizadores de 1829"; ela devia pertencer a Martin Francisco Ribeiro de Andrada ${ }^{73}$. Como os Andrada estavam fora do poder, O Maiorista só podia criticar José Clemente, alvo constante dos exaltados e liberais desde a sua volta à política como homem forte do ministério de 15 de junho de 1828 (em outubro de 1822, ele havia sido exilado por José Bonifácio de Andrada e Silva, juntamente com Joaquim Gonçalves Ledo e outros radicais; José Clemente não tardou em fazer as pazes com o imperador e voltou à política). Quando a lista definitiva dos que portariam as insígnias imperiais foi divulgada, coube ao marquês de Barbacena a honra de carregar a espada do Ipiranga, uma mudança significativa, pois Barbacena havia sido o chefe efetivo do gabinete de 4 de dezembro de 1829 , cuja política era mais tolerante para com a oposição ${ }^{74}$.

A distribuição de títulos de nobreza e de outras honras provocou muitas reclamações. Em abril, Justiniano recomendou que o novo ministério limitasse o número de despachos, mas o governo não aceitou esse conselho. O Maiorista percebeu a notável "exclusão dos partid[ar]istas da Maioridade" e Justiniano, apesar de apoiar o ministério, julgou que muitos cidadãos beneméritos foram esquecidos ${ }^{75}$. O jornalista conservador também repreendeu os Andradistas por demolirem os arcos que haviam levantado para o dia 2 de dezembro de 1840. Quando no poder, resolveram deixá-los em pé até a coroação (com alguns retoques, serviriam perfeitamente para mais uma festa cívica); uma vez fora do poder, não queriam que seus monumentos fossem associados a uma festa controlada por outros ${ }^{76}$. A polêmica entre o bispo do Rio de Janeiro (que também servia de capelão imperial) e o arcebispo da Bahia (o metropolitano do Brasil) sobre quem tinha o direito de sagrar o imperador foi enfim resolvida em favor deste, mas ambos se sentiam obrigados a se justificarem publicamente; recorriam ao direito canônico para disputar a precedência e o privilégio de realizar o ritual ${ }^{77}$.

Apesar dessas dificuldades, nada manchou o espetáculo magnífico que começou na sexta-feira, 16 de julho. Oitenta e cinco coches particulares acompanharam os dez da casa imperial na entrada. Mary Hunter julgou os primeiros muito "ordinários" para uma procissão tão augusta, mas os mais próximos aos da casa imperial eram "muito mais elegantes". O Jornal do Commercio publicou os nomes dos

\footnotetext{
${ }^{70}$ Requerimentos de Corelli à Câmara (com parecer e despacho), Rio, 18 de janeiro de 1841 e 1 de fevereiro de 1841. AGCRJ, 42-313, fols. 49-51.

${ }^{71}$ Requerimento de Valli à Câmara, Rio, maio de 1841; Parecer, Fiscal, freguesia de Santana, 21/ de maio de 1841,.AGCRJ, 42-3-13, fol. $54 \mathrm{r}-\mathrm{v}$.

72 Requerimento de Benard Irmãos à Câmara, Rio, maio de 1841. AGCRJ, 42-3-13, fol. 53.

73 "Os Convites, O Maiorista, 15 de julho de 1841; A Espada do Yprianga. O Maiorista, 08 de julho de 1841.

${ }^{74}$ Relação das pessoas (...) para levarem as insígnias. JC, 10 de julho de 1841. Para o contexto de 1828-1829 ver BARMAN, Roderick J. Brazil... Op. Cit., p. 152-156.

${ }^{75}$ Os Embaraços da Coroação. O Brasil, 24 de abril de 1841; Os Despachos pela Coroação de S. M. I. O Maiorista, 20 de julho de 1841; O Descontentamento Geral. O Maiorista, 22-24 de julho de 1841; A Continuação dos Despachos. O Maiorista, 27 de julho de 1841; Ainda os Despachos da Coroação. O Maiorista, 29 de julho de 1841; Os Despachos da Coroação. O Brasil, 24 de julho de 1841. Para uma defesa dos despachos ver As Graças por occasião da Coroação de S. M. o Imperador. O Despertador, 22 de julho de 1841.

76 Os festejos da coroação. O Brasil, 13 de julho de 1841.

77 ARAUJO, Manuel do Monte Rodrigues. Opúsculo sobre a questão que tivera o excellentissimo arcebispo da Bahia e metropolitano do Brasil, d. Romualdo de Seixas, com o bispo capellão-mór do Rio de Janeiro (...). Rio: Typ. de M. J. Cardoso, 1841; SEIXAS, Romualdo Antônio de Seixas, Memória apologética do arcebispo da Bahia, metropolitano e primaz do Brasil (...). Salvador: Typ. de Galdino José Bizerra e Comp., 1842.
} 
donos desses coches e a lista incluía quase todos os grandes nomes da sociedade imperial ${ }^{78}$.

Em 18 de julho, data marcada para a sagração e a coroação, um "calor terrível” assolou a cidade, segundo o embaixador francês, mas Daniel Kidder julgou a cerimônia "magnífica, muito além das expectativas dos mais otimistas", avaliação compartilhada pelos diplomatas estrangeiros ${ }^{79}$. A coroação propriamente dita começou às $11 \mathrm{~h}$, quando Pedro II deu a ordem para começar a procissão do paço da cidade à capela imperial ${ }^{80}$. Como a procissão seguiu os corredores do palácio e as galerias ou passarelas que os ligavam à capela imperial, a Guarda Nacional formada na praça e a grande multidão mal as vislumbraram, nem as insígnias imperiais (cujos portadores haviam sido tão controversos) ${ }^{81}$. Salvas da Guarda Nacional e os acordes do Hino da Independência acompanharam a procissão. Os espectadores que haviam gasto 320 réis para comprar o programa dos festejos (que incluía a descrição das insígnias imperiais) podiam pelo menos seguir a cerimônia ${ }^{82}$. Na capela imperial foram realizadas a sagração e a coroação diante de um público seleto. $\mathrm{O}$ abade dos Beneditinos pregou sobre I Reis 1:39 ("E Zadoque, o sacerdote (...) ungiu a Salomão") e I Reis 2:12 ("E Salomão se assentou no trono de Davi, seu pai, e o seu reino se fortificou sobremaneira"). Exortou ao imperador e aos seus súditos a cumprirem suas respectivas obrigações: "Nós vós devemos obediência, respeito, fidelidade, e até a nossa vida; mas vós também nos deveis bondade, clemência, justiça e piedade”. A monarquia estava consagrada na Bíblia, explicou o abade, não obstante os esforços dos "modernos políticos, recorrendo a mil hipóteses e imaginando ajustes, pactos sociais, e outras muitas coisas para provar a origem da sociedade humana". Todavia, os benefícios que adviriam aos brasileiros da sua lealdade ao seu soberano eram todos materiais. Depois de enumerá-los, concluiu que "o Brasil, além de mercantil e agricultor, será um país de artistas e fabricantes, manufatureiro" ${ }^{83}$.

Devidamente sagrado e coroado, sobrecarregado de indumentária imperial, d. Pedro II foi apresentado ao seu povo. Da varanda, o alferes-mor anunciou à multidão: "Estai atentos! Está Sagrado o Muito Alto, e Muito Poderoso Príncipe, o Senhor D. Pedro II, por Graça de Deus, e Unânime Aclamação dos Povos, Imperador Constitucional, e Defensor Perpétuo do Brasil. Viva o Imperador!”. Por causa das aclamações da multidão, não foi possível repetir três vezes essa declaração, como mandava o programa, e o imperador ordenou que a Guarda Nacional fizesse as salvas. Apesar do pálio, o jovem coroado não aguentou o calor e, depois da primeira salva, retirou-se à sala do trono onde, flanqueado pelo missal e pela constituição, deu beija-mão. Essa cerimônia foi seguida por um banquete e, às 20h, a varanda foi aberta ao público. Segundo o Jornal do Commercio, doze a quinze mil pessoas desfilaram pela estrutura. A única imagem contemporânea da cerimônia representa o momento em que d. Pedro II foi apresentado ao povo. O artista destacou o papel central da Guarda Nacional e a sua colocação ordeira na praça, mas provavelmente reduziu o tamanho da multidão para destacar o aparato cerimonial (figura 1).

\footnotetext{
${ }^{78}$ HUNTER, Mary Robinson. A diplomat's... Op. Cit., p. 198. Para outras descrições ver Ouseley para Palmerston, Rio, 07 de agosto de 1841. PRO/FO 13, vol. 171, fol. 265r; Coroação de S. M. o Imperador. Entrada na Cidade. O Despertador, 17 de julho de 1841 ; JC, 16-1 de julho de 1841 .

${ }^{79}$ Citado por MOREL, Marco. As transformações dos espaços públicos: imprensa, atores políticos e sociabilidades na cidade imperial. São Paulo: Hucitec, 2005. p. 81; KIDDER, Daniel P. Sketches of residence... Op. Cit., vol. 2, p. 371; BARMAN, Roderick J., Citizen emperor... Op. Cit., p. 84.

${ }^{80} \mathrm{O}$ relato seguinte é baseado no panfleto Disposições para a sagração de S. M. o Imperador. Rio: Typographia Nacional, 1841; e as reportagens publicados no $J C, 20$ de julho de 1841. Schwarcz analisa o panfleto em SCHWARCZ, Lilia Moritz. O Império... Op. Cit. ${ }^{81}$ Sobre as insígnias imperiais, ver SCHWARCZ, Lilia Moritz. As barbas... Op. Cit, p. 78-80; e Idem. O Império... Op. Cit, p. $42-46$. 82 O Guia foi anunciado por esse preço no $J C, 16-17$ de julho de 1841.

83 DAMASO, José de São Bento. Oração gratulatória (...)., JC, 21 de julhoo de 1841.
} 


\section{Figura 1}

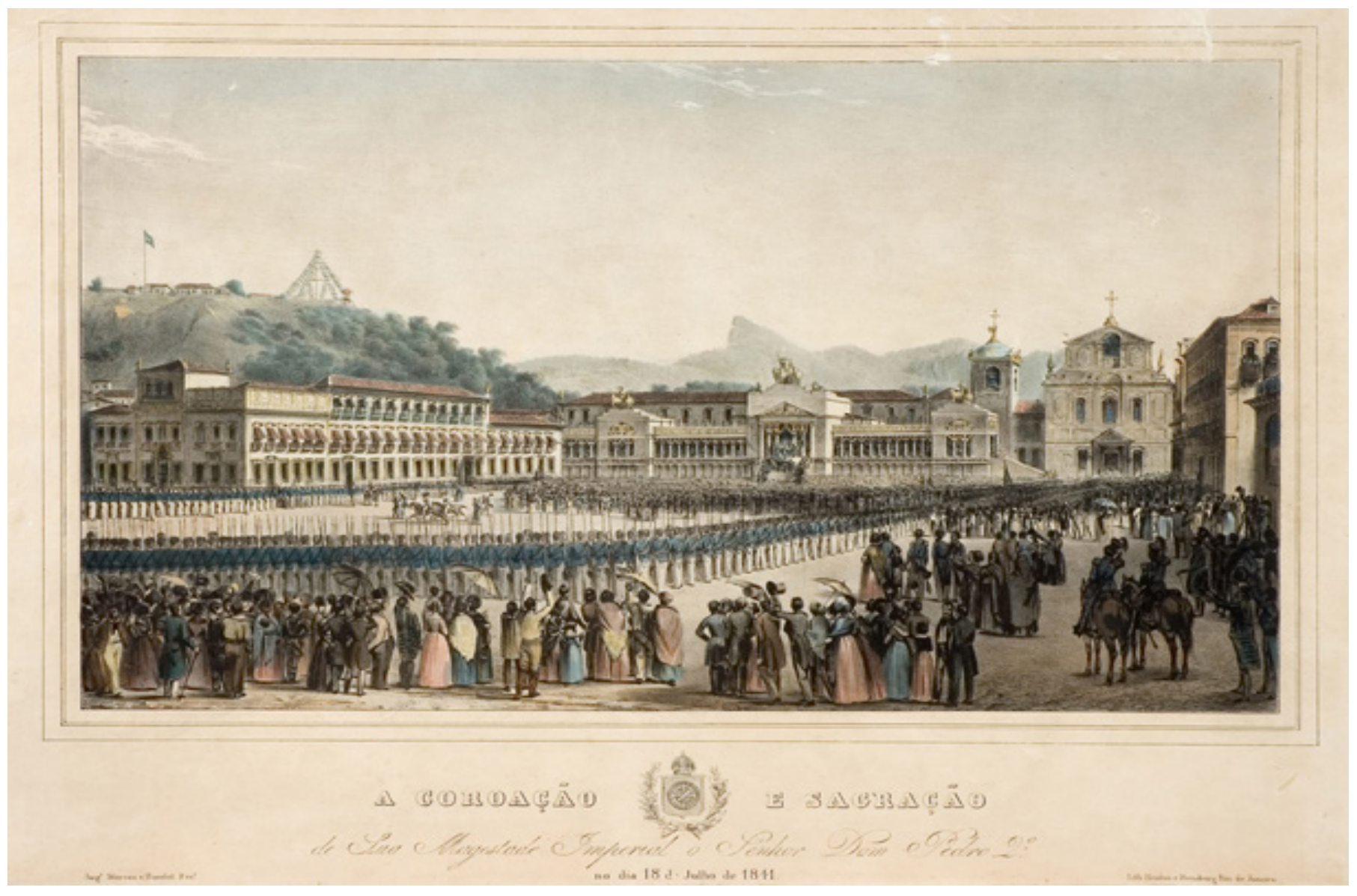

A varanda, cujo preço já foi comentado, ocupou o lado oeste da praça. Tinha um templo principal e dois pavilhões laterais que abrigavam alegorias do Amazonas e do Prata, os dois rios que retoricamente marcavam os limites geográficos do Brasil. O templo, de uma altura de noventa e seis palmos (vinte e um metros), abrigou a sala do trono, magnificamente paramentada. O teto representava d. Pedro I no ato de dar as coroas de Portugal e do Brasil aos seus filhos. Uma pintura alegórica mostrou o novo imperador, "investido do exercício de seus direitos constitucionais", enquanto

as calamidades, os crimes que dilaceravam o império durante o estado anormal e anárquico do país na menoridade fogem espavoridos para o inferno donde haviam saído (...). Ao passo que os vícios se retiram, as ciências, as artes, as virtudes cívicas vêm tomar o seu lugar, e trabalhar, ao abrigo do trono, na prosperidade e glória do império e do monarca.

As duas galerias laterais tinham os nomes de "homens ilustres, beneméritos do Brasil", todos falecidos. Entre eles estavam Pedro Álvares Cabral, Antônio Vieira, Henrique Dias e uma mulher, Catarina Paraguaçu; o último deles era Cláudio Manoel da Costa, o poeta da Inconfidência Mineira. O projeto e o conteúdo das alegorias eram obra de Porto Alegre e de seus alunos da Escola de Belas Artes. O autor da descrição do edifício louvou sua beleza e seu acabamento fino, e lamentou que fosse apenas uma estrutura efêmera ${ }^{84}$. Durante a sua construção, o satirista anônimo julgou-a "um símbolo mui perfeito, um digno representante da nossa época, que é a das construções políticas de pau, feitas para o entusiasmo e funções do momento, e para ser pouco depois desmanchadas e devoradas pelo fogo das rusgas e das revoluções!"

Os festejos da coroação duraram mais uma semana com fogos de artifício, música e monumentos

\footnotetext{
${ }^{84}$ Descrição do edifício construido para solemnidade da coroação e sagração (...). BN/SI, ARC.16.1.1(7); Diario do Rio de Janeiro, 17 de julho de 1841. Ver também SCHWARCZ, Lilia Moritz. As barbas... Op. Cit., p. 74-76, 569n13.

85 As testemunhas (...). JC, 6 de maio de 1841.
} 
iluminados em todas as praças da cidade, um espetáculo de gala no teatro no dia 19 e um grande baile no paço da cidade no dia $24 .{ }^{86}$. D. Pedro II e suas irmãs passearam pela cidade para assistir aos festejos públicos e foram até Laranjeiras no dia $23^{87}$. No dia 20, o Jornal do Commercio publicou o retrato oficial do imperador e uma vista da varanda; aparentemente foram as primeiras imagens publicadas em um periódico brasileiro ${ }^{88}$. O único incidente desagradável ocorreu no dia 22, quando o material pirotécnico guardado no palacete do Campo de Santana pegou fogo. A explosão quebrou vidraças em torno da praça e matou o diretor da fábrica de fogos de artifício e mais dois operários ${ }^{89}$.

Os periódicos da Corte enchiam suas colunas com descrições pormenorizadas dos monumentos efêmeros construídos em todas as freguesias. Como observou Letícia Squeff, foi através da varanda, dos arcos e das outras estruturas que artistas como Porto Alegre procuravam moldar, embora de maneira efêmera, o espaço urbano. Exaltavam a monarquia e representavam publicamente os ideais de beleza ${ }^{90}$. Os arcos continuavam a prática da Renascença, quando foi redescoberta a cultura cívica romana e o seu costume de erigir arcos triunfais. Podem ser interpretados como marcos de um espaço liminar - ao passar debaixo de um arco, o visitante ilustre (ou, neste caso, o monarca a ser coroado) é simbolicamente acolhido pela comunidade -, mas os brasileiros oitocentistas não faziam esse tipo de reflexão. Como foi sugerido por Ian Radforth, construir arcos triunfais era um costume tão fundamente radicado que não havia a necessidade de explicitá-lo ${ }^{91}$.

As poesias e os hinos divulgados durante os festejos da coroação repetiam os temas já consagrados nos festejos do aniversário do imperador em 1837-40. Seu reinado traria a paz e a prosperidade; os poetas conclamavam o jovem imperador a incorporar as virtudes monárquicas e a respeitar a Constituição e lhe ofereceram suas vidas. Louvavam sua ilustre linhagem e convidavam-no a completar e a preservar as obras do seu pai, a Independência e a Constituição. Um poeta liberal foi mais longe e declarou que "O céu não faz os Reis mas sim o Povo" e lembrou o destino de reis malvados, como aquele que perdeu a batalha de Waterloo (Napoleão); recomendou que d. Pedro II servisse a causa de liberdade e defendesse o princípio monárquico nas Américas ${ }^{92}$. O Hino da Coroação, música de Francisco Manoel da Silva e letra de João José de Souza e Silva, articulou os desejos dos brasileiros de forma vaga o suficiente para ser aceita por todos: "Doces laços de concórdia / O Brasil venha prender / Que de Pedro no reinado / Há de a Pátria florescer"93.

Schwarcz observa perspicazmente que a coroação provocou a ampla divulgação da imagem do imperador ${ }^{94}$. Seu retrato apareceu na arquitetura efêmera e até no Jornal do Commercio. As câmaras municipais e outras instituições atualizaram seus retratos oficiais, pois o jovem imperador crescia rapidamente $^{95}$. Medalhas relativamente baratas com a imagem do monarca foram cunhadas e, até o início do século XX, ainda circulavam como dinheiro miúdo ${ }^{96}$. Uma delas tinha a imagem do Brasil representado como um índio pisando em um dragão (símbolo do despotismo ou da anarquia) no ato de coroar seu novo imperador ${ }^{97}$. Todavia, o tom dominante nas representações do monarca, tanto textual como iconográfica, destacava suas origens europeias. De fato, a indumentária imperial incluía

\footnotetext{
${ }^{86}$ Theatro de S. Pedro de Alcantara. O Despertador, 20 de julho de 1841; Theatro de S. Pedro d'Alcantara (folhetim). JC, 21 de julho de 1841; O Baile da Coroação. JC, 26/ de julho de 1841.

87 HUNTER, Mary Robinson. A diplomat's... Op. Cit., p. 200.

88 JC, 20 de julho de 1841.

89 O Incendio do Palacete do Campo e Explosão do Fogo de Artificio. O Despertador, 23 de julho de 1841.

90 SQUEFF, Leticia. O Brasil nas letras de um pintor: Manuel de Araújo Porto Alegre. Campinas: Editora da Unicamp, 2004 . p. 116-119.

${ }^{91}$ RADFORTH, Ian. Royal spectacle: the 1860 Visit of the prince of Wales to Canada and the United States. Toronto: University of Toronto Press, 2004. p. 57-69. Para a análise de alguns desses monumentos ver KRAAY, Hendrik. Days... Op. Cit., p. 104-108. As imagens foram reproduzidas em SANTOS, Francisco Marques do. D Pedro II... Op. Cit., entre p. 86 e 87.

${ }^{92}$ MALTA, I. J. Ao muito alto e poderozo senhor d. Pedro II, imperador constitucional e defensor perpétuo do Brazil (...). Rio: Typ. do Diario de N. L. Vianna, 1841. Para poesias mais típicas ver PEREIRA, Fidelis Honório da Silva dos Santos. Votos a Deos na gloriosa sagração, e coroação de sua magestade imperial o senhor d. Pedro II, imperador constitucional. Rio: Typographia Nacional, 1841; A Faustíssima Coroação. AIHGB, lata 222, doc. 8; Oitava e Soneto. JC, 27 de julho de 1841.

${ }^{3}$ ANDRADE, Ayres de. Francisco Manuel da Silva e seu tempo: Uma fase do passado musical do Rio de Janeiro à luz de novos documentos. Rio: Edições Tempo Brasileiro, 1967. vol. 1, p. 181.

94 SCHWARCZ, Lilia Moritz. As barbas... Op. Cit, p. 127.

95 Documento sem título. 05 de fevereiro de 1841,.AGCRJ, 6-2-25, fol. 38.

96 F. SANTOS, Francisco Marques dos. D. Pedro II... Op. Cit., p. 112.

97 Ibidem, p. 111. Para uma imagem da medalha ver SCHWARCZ, Lilia Moritz. As barbas... Op. Cit., p. 81. 
o famoso manto de penas de tucano, mas este era apenas um ligeiro toque de cor local nos retratos oficiais da época (figura 2).

\section{Figura 2}

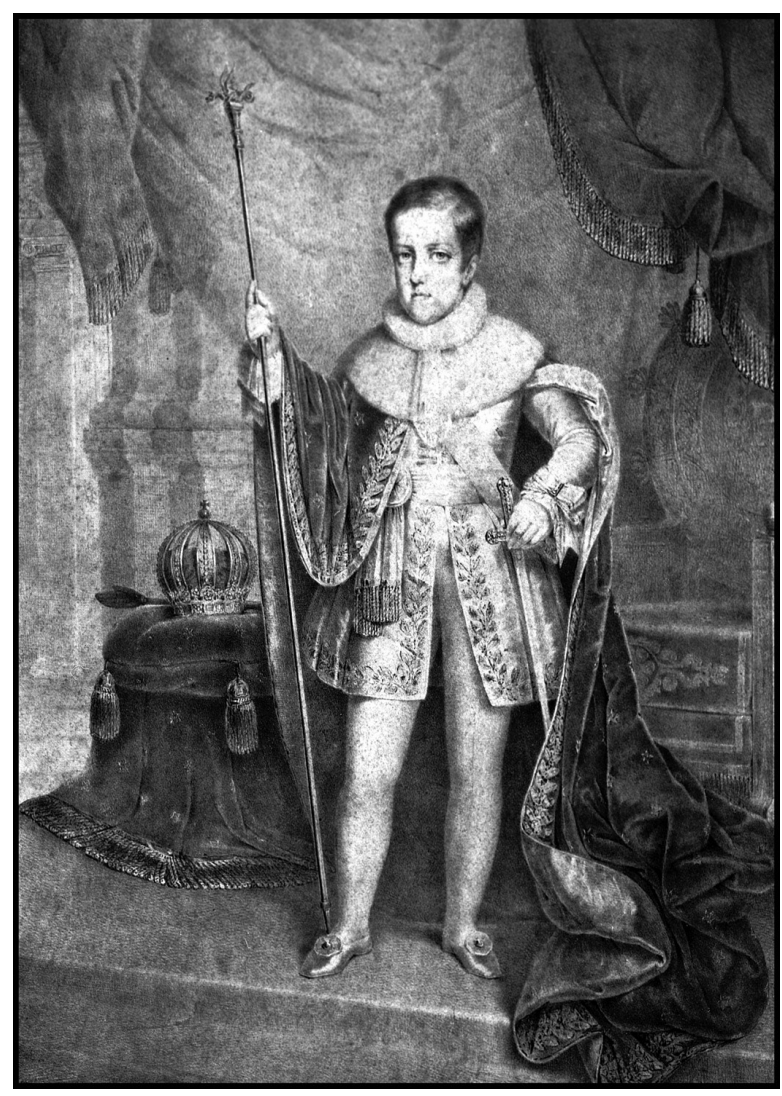

Nos quatro cantos do Império, os brasileiros festejaram a coroação com toda a pompa possível; as elites locais procuraram se ligar à monarquia através dessas comemorações ${ }^{98}$. As notícias das mudanças de datas não chegaram a tempo em Porto Alegre, onde a coroação foi festejada em 23 de maio; o mesmo ocorreu em Sergipe ${ }^{99}$. Felicitações das câmaras municipais e de outras corporações de todo o Brasil encheram as colunas da imprensa fluminense. Em Salvador, houve vários transtornos e enfim foi decidido combinar os festejos oficiais da coroação com os da Independência em 7 de setembro ${ }^{100}$. Em algumas freguesias baianas, todavia, realizaram-se festejos em 18 de julho. O comandante da Guarda Nacional da freguesia de Santana promoveu a construção de um pequeno palco, no qual colocou os retratos de d. Pedro I, d. Pedro II e, curiosamente, o "melhor capitão do século, o grande Napoleão" que nessa alegoria servia de modelo para o imperador brasileiro, ao contrário da referência ao imperador francês na Corte. O presidente assistiu ao te-déum na matriz e descerrou os retratos. Durante três noites a freguesia e a sua praça principal estavam iluminada ${ }^{101}$.

Para as festas oficiais, a assembleia provincial votou vinte contos, boa parte dos quais foram gastos na construção de três monumentos efêmeros nas principais praças da cidade ${ }^{102}$. $\mathrm{O}$ governo suspendeu o recrutamento militar durante os dias dos festejos para incentivar a concorrência ${ }^{103}$. Salvas de artilharia na madrugada do dia 7 de setembro anunciaram o começo da festa. Houve desfile militar,

\footnotetext{
${ }_{98}$ Sobre essa questão ver GRAHAM, Richard. Constructing a nation in nineteenth century Brazil: old and new views on class, culture, and the state. The Journal of the Historical Society, vol. 1, n. 2-3, p. 17-66, 2002.

${ }_{99}$ JC, 4 de julho de 1841; Sergipe. Diario de Pernambuco, Recife, 1 de julho de 1841. O adiamento também causou transtornos em Pernambuco, SANTOS. Lídia Rafaela Nascimento dos. Luminárias, músicas e "sentimentos patrióticos": Festas e política no Recife (1817-1848). Tese (Doutorado em História), Universidade Federal Fluminense, 2018. p. 80-84.

$100 \mathrm{CM}, 13$ de julho de 1841.

101 Festejos pela coroação de S. M. I. na freguesia de Santa Anna (...). O Despertador, 12 de setembro de 1841.

102 CM, 16 de setembro de 1841.

${ }^{103}$ Chefe interino de Polícia para o presidente, Salvador, 4 de setembro de 1841. APEB/SACP, m. 2949. 
te-déum, salvas da Guarda Nacional e vivas ao imperador, às suas irmãs e à Constituição, liderados pelo presidente. No espetáculo de gala, o presidente mais uma vez puxou os vivas e, depois de cantar o Hino Nacional, uma atriz recitou um "brilhante elogio" e poetas glosaram seus versos em honra ao imperador. No dia 9, a Guarda Nacional fez um exercício de fogo no Campo Grande, assistido por 10.000 pessoas; à noite, foi solta uma máquina aerostática do Terreiro de Jesus: "depois de elevar-se a grande altura com toda a serenidade, incendiou-se repentinamente" (aparentemente sem provocar sinistro na cidade ao cair). Na noite do dia 11, um "imenso concurso" afluiu ao Campo Grande para assistir ao espetáculo de fogos de artifício $^{104}$.

O Correio Mercantil lamentou que as "belas festas" haviam sido manchadas pelos "tumultuosos e numerosos batuques de africanos (...) de dia, e às vezes até alta noite”. Havia tantos que pareciam "parte integrante do programa das festas" e um visitante estrangeiro facilmente se imaginava numa "povoação africana". O pior ocorreu no dia 10 quando, não longe dos fogos de artifício no Campo Grande, houve um batuque de 500 pessoas na praça da Piedade ${ }^{105}$. Não se sabe ao certo se houve conexão direta entre esses batuques e a coroação, pois tais festas africanas eram comuns aos domingos e feriados. Todavia, seu tamanho e sua coincidência com os festejos da coroação talvez indiquem leituras populares do conceito de monarquia que o Correio Mercantil não aceitava e talvez nem o compreendesse. $\mathrm{O}$ que é claro é que esse jornal rejeitava a presença africana ao lado das festas cívicas brasileiras, da mesma forma que a polícia da Corte procurou afastar escravos e quitandeiras do largo do Paço ${ }^{106}$.

Nada semelhante aos batuques criticados pelo Correio Mercantil foi registrado pelos periódicos da Corte, mas houve escravos que refletiam sobre o significado da coroação. Em maio de 1841, o dono de uma fazenda contígua à fazenda imperial de Santa Cruz reclamou que os escravos do imperador diziam que "todos os pretos ficariam forros" no dia da coroação ${ }^{107}$. O boato, semelhante aos que corriam na época da Independência (alguns escravos acreditavam que a liberdade política do Brasil implicava na sua liberdade) não era inteiramente infundado. No final de julho, d. Pedro II libertou vinte músicos escravos que tocaram ou cantaram durante os festejos, mas os trabalhadores da Santa Cruz permaneciam no cativeiro. ${ }^{108}$ Os relatos da coroação na imprensa fluminense sugerem que as autoridades conseguiram dominar as ruas da capital ou que os jornalistas mantiveram silêncio sobre as festas populares que ocorriam, tudo no intuito de apresentar um ritual bem sucedido e ordeiro. Em todo caso, esses relatos revelam as dificuldades em apreender o imaginário popular da monarquia ${ }^{109}$.

Os esforços para promover o ritual monárquico que começaram com o Regresso culminaram na coroação. Como explicou Kidder, "pensava-se que era um objeto de primeira importância rodear o trono com tanto esplendor que o consagrasse para sempre nos olhos do povo" ${ }^{110}$. Justiniano avaliou a coroação da mesma forma, e esperava que levasse ao esquecimento das divergências partidárias, mas concluiu numa nota pessimista: "É talvez quimérica essa nossa pretensão"111. Kidder, que deixou o Brasil pouco depois da coroação, se preocupou que o espetáculo "geraria uma predileção mórbida por cenas de cerimônias extraordinárias, que só seria satisfeita com sua repetição frequente" 112 . Apesar da preocupação do viajante, não houve festas cívicas do porte da coroação por muitos anos. Da mesma forma que o entusiasmo pelos festejos da Constituição e da Independência diminuía à medida que definhava o movimento exaltado ${ }^{113}$, o destaque à monarquia da parte dos regressistas diminuiu logo

\footnotetext{
$\overline{{ }^{104} C M, 16 \text { de setembro de } 1841 .}$

${ }^{105} \mathrm{CM}, 30$ de setembro de 1841.

${ }^{106}$ REIS, João José. Tambores e temores: A festa negra na Bahia na primeira metade do século XIX. In: CUNHA, Maria Clementina Pereira (org.). Carnavais e outras $f(r)$ estas: Ensaios de história social da cultura. Campinas: Editora da Unicamp, 2002. p. 121-129, 138-139.

107 SOARES, Carlos Eugênio Líbano. A capoeira escrava e outras tradições rebeldes no Rio de Janeiro (1808-1850). Campinas: Editora da Unicamp, 2001. p. 410.

108 BARMAN, Roderick J. Citizen emperor... Op. Cit., p. 85, $441 \mathrm{ln} 44$.

109 SCHWARCZ, Lilia Moritz. As barbas... Op. Cit., cap. 10; e SOUZA, Iara Liz Carvalho. Pátria coroada...Op. Cit., p. 230-232. Ver também REIS, João José. Quilombos e revoltas escravas no Brasil. Revista USP, n. 28, p. 32-33, 1995-1996.

110 KIDDER, Daniel P. Sketches of residence... Op. Cit., vol. 2, p. 372.

111 A Coroação e Sagração de S. M. I. O Brasil, 22 de julho de 1841.

112 KIDDER, Daniel P. Sketches of residence... Op. Cit., vol. 2, p. 372.

${ }^{113}$ BASILE, Marcello. Festas cívicas na Corte regencial. Vária História, vol. 22, n. 36, p. 494-516, 2006; KRAAY, Hendrik. Days... Op. Cit., p. 53-81.
} 
depois da coroação. Ao contrário da fórmula de Geertz, na qual a política e o estado balinês serviam ao ritual, no Brasil, o ritual imperial servia aos interesses dos que controlavam o Estado. Mas não havia como controlar o discurso sobre as festas cívicas num país com uma imprensa livre e com divisões partidárias tão acirradas que, no ano seguinte à coroação, levariam às revoltas liberais de São Paulo e Minas Gerais, depois que o imperador exerceu o poder moderador para dissolver a Câmara dos Deputados eleita em 1840 pelo gabinete da Maioridade ${ }^{114}$.

\section{Referências bibliográficas}

ANDRADE, Ayres de. Francisco Manuel da Silva e seu tempo: Uma fase do passado musical do Rio de Janeiro à luz de novos documentos. Rio: Edições Tempo Brasileiro, 1967.

ARAUJO, Dilton Oliveira. O Tutu da Bahia: transição conservadora e formação da nação, 1838-1850. Salvador: EdUFBa, 2009.

ARAUJO, Manuel do Monte Rodrigues. Opúsculo sobre a questão que tivera o excellentissimo arcebispo da Bahia e metropolitano do Brasil, d. Romualdo de Seixas, com o bispo capellão-mór do Rio de Janeiro (...). Rio: Typ. de M. J. Cardoso, 1841.

BARMAN, Roderick J. Brazil: The forging of a nation, 1798-1852. Stanford: Stanford University Press, 1988. Press, 1988.

Citizen emperor: Pedro II and the making of Brazil, 1825-1891. Stanford: Stanford University

BASILE, Marcello. Festas cívicas na Corte regencial. Vária História, vol. 22, n. 36, p. 494-516, 2006.

. O laboratório da nação: A era regencial (1831-1840). In: GRINBERG, Keila; SALLES, Ricardo (org.). O Brasil imperial. Rio de Janeiro: Civilização Brasileira, 2009. vol. 2: 1831-1870. p. 53-119.

BERTRAND, Arthur. Lettres sur l'expédition de Saint-Hélène en 1840. Paris: Paulin, 1841.

BIRNBAUM, N. Monarchists and sociologists: a reply to professor Shils and Mr. Young. Sociological Review, vol. 3, n. 1, p. 5-24, julho de 1955.

BOTAFOGO, Antôonio Joaquim de Sousa. O balanço da dynastia. Rio: Imprensa Nacional, 1890.

BUC, Phillippe. The dangers of ritual: between early medieval texts and social scientific theory. Princeton: Princeton University Press, 2001.

CASTRO, Pedro Paulo. A “experiência republicana”, 1831-1840. In: HOLANDA, Sérgio Buarque de. História geral da civilização brasileira. São Paulo: Difusão Européia do Livro, 1964. tomo 2, vol. 2: Dispersão e unidade, p. 9-67.

COGGESHALL, George. Thirty-six voyages to various parts of the world, made between the years 1799 and 1841. $3^{\mathrm{a}}$ ed. Nova York: Published by and for the Author, 1858.

Disposições para a sagração de S. M. o Imperador. Rio: Typographia Nacional, 1841.

GEERTZ, Clifford. Negara: the theater state in nineteenth century Bali. Princeton: Princeton University Press, 1980.

GRAHAM, Richard. Constructing a nation in nineteenth century Brazil: old and new views on class, culture, and the state. The Journal of the Historical Society, vol. 1, n. 2-3, p. 17-66, 2002.

HAMOND, Graham Eden. Os diários do almirante (...), 1825-1834/38. Tradução de Paulo F. Geyer. Rio: Editora J. B., 1984.

HÖRNER, Erik. Até os limites da política: a "Revolução Liberal” de 1842 em São Paulo e Minas Gerais. São Paulo: Alameda, 2014.

HUNTER, Mary Robinson. A diplomat's lady in Brazil: Selections from the diary of Mary Robinson Hunter, 1834-1848. Organização de Evelyn M. Cherpak. Newport: Newport Historical Society, 2001.

JENKINS, John S. United States exploring expeditions (...). Auburn: James M. Alden, 1850.

KERTZER, David I. Ritual, politics, and power. New Haven: Yale University Press, 1988.

KIDDER, Daniel P. Sketches of residence and travels in Brazil. Philadelphia: Sorin \& Ball, 1845.

KRAAY, Hendrik. Days of national festivity in Rio de Janeiro, Brazil, 1823-1889. Stanford: Stanford University

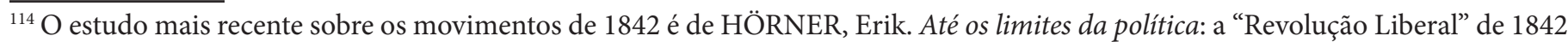
em São Paulo e Minas Gerais. São Paulo: Alameda, 2014.
} 
Press, 2013.

"Tão assustadora quanto inesperada": a Sabinada baiana, 1837-1838. In: DANTAS, Mônica Duarte (org.). Revoltas, motins, revoluções: homens livres pobres e libertos no Brasil do século XIX. São Paulo: Editora Alameda, 2011. p. 263-294.

LOPEZ, Emilio Carlos Rodrigues. Festas públicas, memória e representação. São Paulo: Humanitas, 2004.

MALTA, I. J. Ao muito alto e poderozo senhor d. Pedro II, imperador constitucional e defensor perpétuo do Brazil (...). Rio: Typ. do Diario de N. L. Vianna, 1841.

MELLO MORAES FILHO, Alexandre José de. História e costumes. Rio: B. L. Garnier, 1904.

MOREL, Marco. As transformações dos espaços públicos: Imprensa, atores políticos e sociabilidades na cidade imperial. São Paulo: Hucitec, 2005.

NEEDELL, Jeffrey D. The Party of Order: the conservatives, the state, and slavery in the Brazilian Monarchy, 1831-1871. Stanford: Stanford University Press, 2006.

OLIVEIRA, Eduardo Romero. O império da lei: Ensaio sobre o cerimonial de sagração de D. Pedro I (1822). Tempo, vol. 13, n. 20, p. 133-159, 2009.

PARRON, Tâmis. A política da escravidão no Império do Brasil, 1826-1865. Rio: Civilização Brasileira, 2001.

PEREIRA, Fidelis Honório da Silva dos Santos. Votos a Deos na gloriosa sagração, e coroação de sua magestade imperial o senhor d. Pedro II, imperador constitucional. Rio: Typographia Nacional, 1841.

RADFORTH, Ian. Royal spectacle: the 1860 visit of the prince of Wales to Canada and the United States. Toronto: University of Toronto Press, 2004.

REIS, João José. Quilombos e revoltas escravas no Brasil. Revista USP, n. 28, p. 14-39, 1995-1996.

Tambores e temores: a festa negra na Bahia na primeira metade do século XIX. In: CUNHA, Maria Clementina Pereira (org.). Carnavais e outras f(r)estas: Ensaios de história social da cultura. Campinas: Editora da Unicamp, 2002. p. 101-155.

REYNOLDS, William. Voyage to the Southern ocean. Organização de CLEAVER, Anne Hoffman; STANN, E. Jeffrey. Annapolis: Naval Institute Press, 1988.

RIBEIRO, Maria Eurydice de Barros. Os símbolos do poder: cerimônias e imagens do Estado monárquico no Brasil. Brasília: UnB, 1995.

SANTOS, Francisco Marques dos. Dom Pedro II e a preparação da Maioridade. Estudos Brasileiros, vol. 3, n. 7, p. 40-140, 1941.

SANTOS. Lídia Rafaela Nascimento dos. Luminárias, músicas e "sentimentos patrióticos": festas e política no Recife (1817-1848). Tese (Doutorado em História), Universidade Federal Fluminense, 2018.

SCHUBERT, Guilherme. A coroação de d. Pedro I. Rio: Arquivo Nacional, 1973.

SCHWARCZ, Lilia Moritz. As barbas do imperador: d. Pedro II, um monarca nos trópicos. 2a ed. São Paulo: Companhia das Letras, 1999.

SCHWARCZ, Lilia Moritz. O Império em procissão. Rio: Jorge Zahar, 2001.

SEIXAS, Romualdo Antônio de Seixas. Memória apologética do arcebispo da Bahia, metropolitano e primaz do Brasil (...). Salvador: Typ. de Galdino José Bizerra e Comp., 1842.

SERVA, Manoel Antônio da Silva. O Dous de Dezembro de 1839 (...). Salvador: Typ. de Manoel Antonio da Silva Serva, 1839.

SHILS, Edward; YOUNG, Michael. The meaning of the coronation. The Sociological Review, vol. 1, n. 2, p. 63 81, dezembro de 1953.

SOARES, Carlos Eugênio Líbano. A capoeira escrava e outras tradições rebeldes no Rio de Janeiro (1808-1850). Campinas: Editora da Unicamp, 2001.

SOUZA, Iara Lis Franco Schiavinatto Carvalho. Pátria coroada: o Brasil como corpo político autônomo, 17801831. São Paulo: Editora Unesp, 1998.

SOUZA, Paulo Cesar. A Sabinada: a revolta separatista da Bahia (1837). São Paulo: Brasiliense, 1987.

SQUEFF, Leticia. O Brasil nas letras de um pintor: Manuel de Araújo Porto Alegre. Campinas: Editora da Unicamp, 2004.

TITARA, Ladislau dos Santos. Obras poéticas dedicados à ill. ${ }^{\text {ma }}$ senhora d. Ignacia Maria de Carvalho Lima. Salvador: Typ. de G. J. Bizerra e Companhia, 1839.

WILKES, Charles. Narrative of the United States exploring expedition during the years $1838,1839,1840,1841$, 
1842. Nova ed. Nova York: George P. Putnam, 1851.

Recebido em: 20/03/2018 - Aprovado em: 13/10/2018 